\title{
APPLYING THE PHENOMENON OF REAL ESTATE MARKET SUBJECT TRANSLOCALITY TO DETERMINE THE REGIONAL DEVELOMPENT LEVEL OF POLISH VOIVODESHIPS
}

\author{
Justyna Brzezicka, M.Sc. \\ Faculty of Geodesy, Geospatial and Civil Engineering \\ University of Warmia and Mazury in Olsztyn \\ e-mail: justyna.brzezicka@uwm.edu.pl \\ Radoslaw Wisniewski, assoc. prof., PhD \\ Faculty of Geodesy, Geospatial and Civil Engineering \\ University of Warmia and Mazury in Olsztyn \\ e-mail:danrad@uwm.edu.pl
}

\begin{abstract}
The article pertains to the issue of subject translocality on the real estate market and indicates the scope of its practical application connected with determining the level of the economic development of voivodeships. The issue of real estate market subject translocality was analyzed on the basis of a review of literature connected with the locality of the real estate market in its subject plane, as well as by setting apart a category referring to the subject plane of the real estate market. The work is of an empirical nature. In this part, coefficients of real estate market subject translocality were used in order to assess the level of development of individual voivodeships. Cluster analysis was also used in order to establish the groups of voivodeships similar in terms of the level of real estate market subject translocality.
\end{abstract}

Key words: real estate market, real estate market locality, real estate market translocality, locality, translocality.

JEL Classification: R28, R30, R58.

Citation: Brzezicka J. Wisniewski R., 2015, Applying the Phenomenon of Real Estate Market Subject Translocality to Determine the Regional Development Level of Polish Voivodeships, Real Estate Management and Valuation, Vol. 23, No. 2, pp. 27-37.

DOI: 10.1515/remav-2015-0013

\section{Introduction}

The current view of the real estate market through the prism of its object plane, that is the one connected with the real estate and its servicing, is undergoing gradual evolution. The behaviors of active subjects, displaying characteristics of changing the structure of the real estate market, are becoming the axis of the observed changes. The behaviors of participants in the real estate market system are becoming especially important due to generating long-term effects, the accurate prognosis of which is faced with many difficulties. The reason behind this is the existence of so-called "soft factors". At the same time, over the recent years, studies connected with the real estate market have become especially valuable due to, among others, the construction sector activating the economy, or by affecting financial markets providing capital for investments. The indirect influence of the real estate market in the international economic crisis (KUCHARSKA-STASIAK et al. 2012, p. 45) is also a 
serious issue, encouraging the observation of the market and behaviors occurring within it with greater detail.

The work assumed two detailed aims which have been formulated in the following way: 1) presenting the phenomenon of real estate market subject translocality, which completely falls into the issue outlined above, as well as 2) adapting a set of research instruments on the discussed phenomenon for the needs of determining groups of similar voivodeships, as well as the rate and level of economic development of regions. An intermediate aim of the work was to present, in the Polish setting, the phenomenon of translocality, which is known from global literature reports. The research thesis is connected with the conviction regarding the significant role of the real estate market among other sectors of the economy, due to its activating role on economy, as well as reflecting social needs and demographic changes by revealed market demand. These premises make it possible to formulate the research hypothesis, according to which monitoring the state of the market while employing the issue of subject translocality makes it possible to determine the development level of regions.

A review of literature was used to carry out the theoretical part of this work, enabling the assumed subject matter to be grounded in academic achievements, as well as cluster analysis, representing an integral, empirical part of the work. The authors understand the article builds on scientific knowledge in the scope of the real estate market, introducing new elements concerning the significance of the subject side of the real estate market, as well as the means of monitoring the condition of the market and level of local development.

\section{Short characterization of the real estate market structure}

A starting point for the identification and description of the phenomenon of real estate market subject translocality is the observed inconsistency of terminology regarding real estate market locality. The locality of the market can and ought to be connected with the object plane of the market (immobile real estate), but it appears to remain in conflict as regards to the subject plane of the real estate market (mobile subjects). As noted by GoŁĘBSKA (2007, p. 39), "the real estate market is made up of, above all, two subjects: the buyer and the seller. Without their participation, it would be difficult to talk about a market in the first place, which (...) is connected with a purchase-sale transaction between the two participants of this transaction." This observation calls for distinguishing a new research category of the real estate market - a category characterizing the subject plane of the market, which exceeds its local dimension, thus the expression of real estate market subject translocality. In this perspective, local real estate markets are composed of a local object plane, which builds a passive image of the market (the source of passiveness is the immobility of real estate), as well as a market plane represented by the active subject side, built by mobile subjects. Both of the mentioned research categories, analyzed simultaneously, will make it possible to notice an important aspect of the real estate market, i.e. its translocality. The above-described dependencies have been presented in Fig. 1, whereas detailed considerations regarding the local and translocal dimension of the real estate market have been assumed in the following chapters of the work.

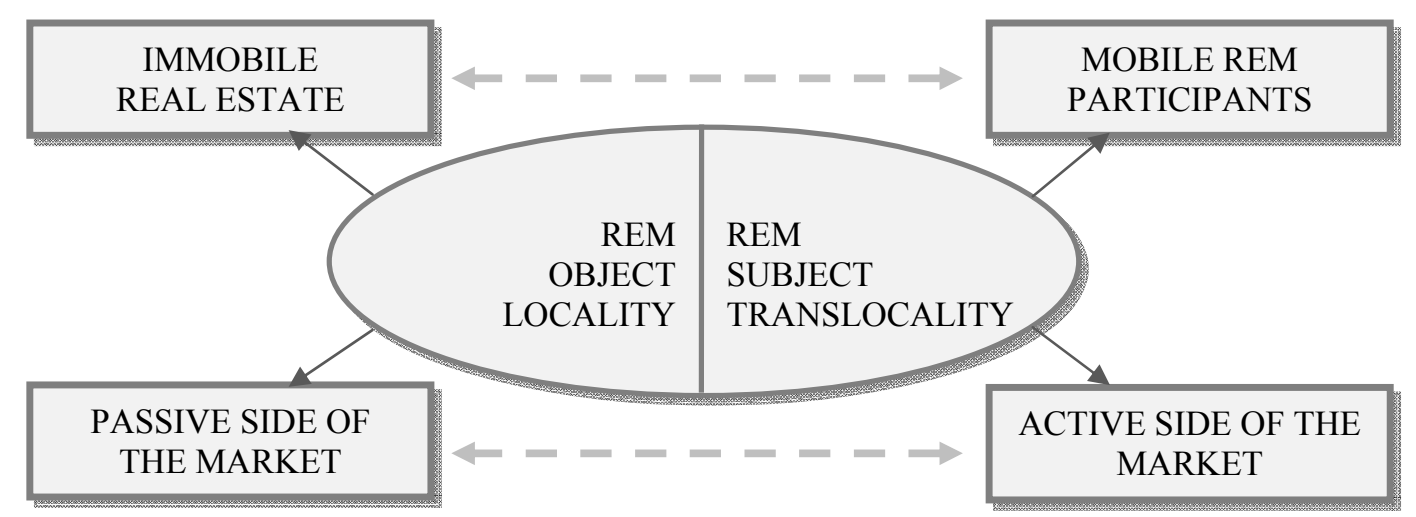

Fig. 1. Real estate market structure - division into categories. Source: own elaboration.

\section{Real estate market object locality}

The axis of studies on the real estate market, founded on a many-year scientific tradition, is the conviction regarding the local nature of the real estate market (GALATY el al. 2003, p. 4; GELTNER 2007, 
p. 4, GŁóWKA 2008, p. 18; HAILA 2000; LUCIUS 2001, p. 75; LUSHT 1988; SIEMIŃSKA 2011, p. 19), resulting from real estate being connected with the place where it is located. The permanence of real estate in a given place, otherwise referred to as immobility (GŁÓWKA 2008, SIEMIŃSKA 2011, p. 19), is considered a permanent characteristic trait of the real estate market. Using the category of "real estate market locality" is justified in the light of legal, structural, and functional premises of the real estate market.

Legal premises of the real estate market result from the statutory definition of real estate. According to art. 46 of the Act of 23 April 1964 Civil Code, "real estate are parts of the Earth's surface, constituting an individual object of ownership (land), as well as buildings permanently connected with the ground or parts of such buildings if under specific rights, they are an object of ownership separate from the land." In the above-quoted definition, two elements ought to be emphasized: parts of the earth's surface and buildings permanently connected with the ground. Land and buildings are permanent, and their relocation is an uncommon occurrence (KUCHARSKA-STASIAK 2006, p. 20). The legal determinant of locality is connected and results from local institutional order (KUCHARSKA-STASIAK et al. 2012, p. 17). In this perspective, market space becomes restricted to the place where the real estate is found. Structural determinant of real estate market locality result from the fact that "real estate awaits demand for it" (KUCHARSKA-STASIAK 2006, p. 20). As a result of this, the locality of the real estate market is determined by the demand for real estate which is (in a short period) "located", that is prescribed a given location under the assumption that demand is more mobile (KAŁKOWSKI 2001, p. 24). HOPFER and CELLMER (1997, p. 37) emphasize that the extent of demand for rights to real estate in a given location as well as geographical extent of the market are a manifestation of the spatial dimension of the real estate market (market structure). Functional determinants, on the other hand, are primarily the necessity of fulfilling the needs of the local society (flats, places of work, education, entertainment) by the real estate. The individual described determinants of the REM are together served by the market infrastructure, which can be understood in many ways: as the area of work of property valuers, the range in which public administration organs operate, or the living space of market participants.

The above described determinants have been presented in Figure 2. At the same time, it is believed that the above solutions have made it possible to fully elaborate on the issue of real estate market locality in its current understanding. The most important conclusion derived from them regards the necessity of connecting real estate market locality with the immobility of real estate and the territorial dimension of the market.

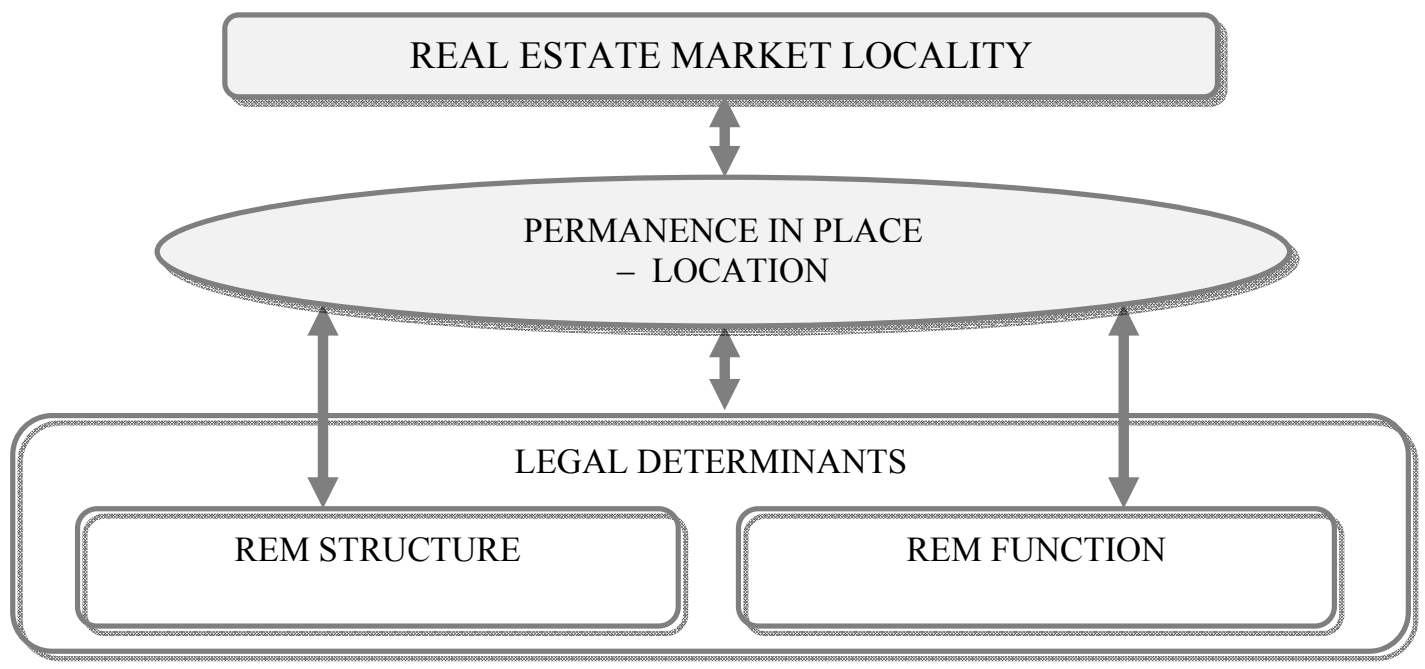

Fig. 2. Determinants of real estate market locality. Source: own elaboration.

\section{Subject translocality of the real estate market}

Before attempting to describe real estate market translocality, the grounding of the issue of translocality in current scientific output deserves commentary. Translocality is an relatively new topic, often connected with issues of traditional ethnography (APPADURAI 1996, p. 192; HANNERZ 1998, p. 239); transnational urbanism (SMITH 2001); local, translocal and transnational closing of multi-aspect bonds (SMITH 2005, p. 7); globalization(FREITAG, VON OPPEN 2009); widely understood migrations 
(GREINER AND SAKDAPOLRAK 2013); or a supranational dimension of cultural findings (ELAFROS 2013; HALL, DATTA 2010; MA 2002). An interesting description was proposed by Smith (2001), according to which translocality can be understood as a network connection of socio-cultural and political processes in which migrating subjects build and create connections between towns in individual countries, maintain new political, economic and cultural courses, extending their own significance over time. On the basis of the outlined area of interest of the phenomenon of translocality, two observations appear worth drawing attention to. Firstly, translocality does not remain in direct opposition to locality, but is its elaboration, opens many new directions of research and emphasizes the network nature of the discussed phenomena. Secondly, translocality reveals and exposes the significance of subjects who migrate, move around, or in a general understanding, experience specific development in the spatial, global and cultural dimension. The listed dimensions are only a representation of the strength and activeness of subjects, and are of an open nature, with this openness becoming a characteristic trait of translocality.

The above observations along with the behaviors of subjects in the real estate market system make it possible to specify the nature of subjects. Above all, as indicated earlier, subjects are mobile. Up to now, the understanding of subject mobility had a traditional character - mobility in the context of crossing territorial barriers, movement, migrations. At the same time, in the light of the newest research this characteristic does not seem to fully reflect the nature of market subjects. The newest studies of an interdisciplinary character, especially behavioral approaches in economics, founded on the findings of psychology and sociology put the analysis of individual human behaviors and social groups at the center of studies. These schools of thought are becoming more and more popular in regards to the real estate market, also in the Polish setting (see, e.g. RZEZICKA, WISNIEWSKI 2014a, 2014b; KŁOBUKOWSKa 2014; MASIUKIEWICZ, DeC 2013). Subjects in the real estate market system, according to the behavioral approach, are active, dealing with market obstacles in a creative manner, and reveal real estate market system changing properties. This means that their behaviors are closer to the model of the real human (BRZEZICKA, WISNIEWSKI 2014D) rather than to the opposing economic human (homo economicus) model. In specific market conditions existing on the real estate market, i.e. information shortages of this market (WISNIEWSKI 2007a; BRZEZICKA, WISNIEWSKI 2014c), with its poor informative effectiveness (WISNIEWSKI 2007b) and permanent states of uncertainty occurring on this market - the subjects realize their own investment strategies and life plans.

Thus, the classic definition of mobility is too narrow and restrictive. This concept ought to be expanded on. The carried out studies make it possible to combine the above-described subject mobility in the spatial sense with mobility in the sphere of their behaviors. Based on this, a new characterization of market subjects is born - translocal subjects. Translocal subjects are defined as "active participants of the real estate market, apt to relocate within boundaries set by conscious or subconscious strategies of realizing their own aims, who thanks to their own activity reveal a real estate market system changing property" (BRZEZICKA, WISNIEWSKI 2015). Such a view of subject behaviors in regards to mobility (horizontal relocation) and translocality (vertical relocation, that is relocation connected with the subjects' own sphere of behaviors) makes it possible to give the market structure a translocal character - translocal subjects carry translocality over to the real estate market, giving it a translocal character.

Real estate market translocality can be defined (BRZEZICKA, WISNIEWSKI 2015) by its unspecific ability to dynamically change structure, relocate and change, in time and space, the mechanisms of functioning determined by the aggregate of changes at the procedural, subject and object level, as well as the relations between them, taking place with the participation of subject plane of the real estate market. The phenomenon of translocality ought to be understood in a multi-faceted and systemic manner, and be referred to the occurrence of many different behaviors on the real estate market, which are the axis of significant changes in the local and global dimension. At the same time, the carried out considerations made it possible to increase familiarity with the phenomenon of real estate market subject translocality. An implication of exhausting the topic is the conviction that the first task set out by the present work has been realized.

\section{Empirical research}

\subsection{Assumptions made in the study}

The empirical part of the work was realized based on real estate market subject translocality coefficients calculated for all Polish voivodeships. The study made use of data published by the Main 
Statistical Office, regarding the number of people and housing resources in reference to units of territorial division (all voivodeships). The calculations were also carried out for the area of the entire country to make it possible to find the average result and refer the obtained results of the individual voivodeships to those for entire country. The voivodeships were labeled according to the first letter (without Polish symbols) of the name of the voivodeship, whereas results obtained for the entire country were marked as P (Poland). The symbols of the names of the voivodeships have been compiled into Table 1.

Table 1

Descriptions of voivodeships used in the studies

\begin{tabular}{|c|c|c|c|c|c|}
\hline No. & Symbol & Name of Voivodeship & No. & Symbol & Name of Voivodeship \\
\hline 1 & L & Łódzkie & 9 & L3 & Lubuskie \\
\hline 2 & M & Mazowieckie & 10 & W & Wielkopolskie \\
\hline 3 & M2 & Małopolskie & 11 & Z & Zachodniopomorskie \\
\hline 4 & S & Śląskie & 12 & D & Dolnośląskie \\
\hline 5 & L2 & Lubelskie & 13 & O & Opolskie \\
\hline 6 & P2 & Podkarpackie & 14 & KP & Kujawsko-pomorskie \\
\hline 7 & P3 & Podlaskie & 15 & P4 & Pomorskie \\
\hline 8 & S2 & Świętokrzyskie & 16 & WM & Warmińsko-Mazurskie \\
\hline
\end{tabular}

Source: compiled by the authors.

\subsection{Coefficients of real estate market subject translocality - methodology}

The assumed methodology of calculating coefficients was in accordance with that provided in the research paper of Brzezicka and Wisniewki (2015), and has been presented below. For the needs of realizing the aims of the article, only two $\left(W_{0}\right.$ and $\left.W_{1}\right)$ of the three proposed coefficients proposed in the above-mentioned work were applied (BRZEZICKA, WISNIEWSKI 2015).

The zero coefficient of real estate market subject translocality $\left(W_{0}\right)$ describes the number of people per one dwelling and is of a linear nature. It was calculated according to the following formula (1):

$$
\mathbb{W}_{\mathrm{p}}=\frac{z_{\mathrm{r}}}{M_{\mathrm{r}}}
$$

where:

$L_{t} \quad$ - population in year $t$,

$M_{t} \quad$ - number of dwellings in year $t$.

The first real estate subject translocality coefficient $\left(W_{1}\right)$ expresses the relation between the dynamics of the number of people and the dynamics of the number of dwellings. Dynamics in this case are understood as indicators of the increase in the number or dwellings and number of people in the year $t$, assuming that the number of people / number of dwellings in year $t-1=100$. The following formula was used to carry out calculations (2):

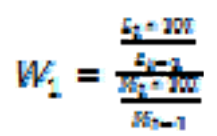

where:

$$
\begin{array}{ll}
L_{\mathrm{t}} & \text { - population in the year } t, \\
M_{t} & \text { - number of dwellings in the year } t, \\
t & \text { - year } t .
\end{array}
$$

The $W_{1}$ subject translocality coefficient was calculated to indicate that the dynamics of the real estate market in the subject approach (changes in population) and dynamics of the real estate market in the object approach (changes in the number of dwellings), do not exhibit a one-directional relationship. The index of the number of people to the number of dwellings does not make it possible to observe a discrepancy between the subject and objects side of the REM. In order to observe such a discrepancy, the $W_{1}$ coefficient was constructed, based on indexes of dynamics. The role of $W_{1}$ relies on emphasizing that the dynamics of the number of dwellings and population varies in the individual years and is not unidirectional (increases and decreases). 


\subsection{Results of research}

Real estate market subject translocality was calculated based on the $W_{0}$ and $W_{1}$ coefficients over a 5year time span, during the years 2008-2012. The results have been compiled in Table 2.

Table 2

Coefficients of real estate market subject translocality - results

\begin{tabular}{|c|c|c|c|c|c|c|c|c|c|c|}
\hline \multirow{2}{*}{ Year / unit } & \multicolumn{9}{|c|}{$W_{0}$} & \multicolumn{6}{c|}{$W_{1}$} \\
\cline { 2 - 12 } & $\mathbf{2 0 0 8}$ & 2009 & 2010 & 2011 & 2012 & 2008 & 2009 & 2010 & 2011 & 2012 \\
\hline P & $\mathbf{2 . 9 0 0}$ & $\mathbf{2 . 8 6 9}$ & $\mathbf{2 . 8 6 0}$ & $\mathbf{2 . 8 3 6}$ & $\mathbf{2 . 8 0 8}$ & $\mathbf{0 . 9 8 9}$ & $\mathbf{0 . 9 8 9}$ & $\mathbf{0 . 9 9 7}$ & $\mathbf{0 . 9 9 2}$ & $\mathbf{0 . 9 9 0}$ \\
\hline L & 2.648 & 2.626 & 2.605 & 2.583 & 2.556 & 0.990 & 0.992 & 0.992 & 0.992 & 0.990 \\
\hline M & 2.650 & 2.610 & 2.553 & 2.534 & 2.510 & 0.984 & 0.985 & 0.978 & 0.993 & 0.990 \\
\hline M2 & 3.104 & 3.061 & 3.100 & 3.076 & 3.042 & 0.987 & 0.986 & 1.013 & 0.992 & 0.989 \\
\hline S & 2.733 & 2.714 & 2.732 & 2.714 & 2.694 & 0.992 & 0.993 & 1.007 & 0.993 & 0.993 \\
\hline L2 & 3.015 & 2.985 & 2.973 & 2.940 & 2.907 & 0.988 & 0.990 & 0.996 & 0.989 & 0.989 \\
\hline P2 & 3.415 & 3.391 & 3.435 & 3.409 & 3.380 & 0.993 & 0.993 & 1.013 & 0.992 & 0.991 \\
\hline P3 & 2.905 & 2.874 & 2.863 & 2.830 & 2.797 & 0.988 & 0.989 & 0.996 & 0.988 & 0.988 \\
\hline S2 & 3.029 & 3.009 & 3.015 & 2.986 & 2.958 & 0.992 & 0.994 & 1.002 & 0.990 & 0.991 \\
\hline L3 & 2.937 & 2.908 & 2.919 & 2.893 & 2.870 & 0.988 & 0.990 & 1.003 & 0.991 & 0.992 \\
\hline W & 3.154 & 3.125 & 3.100 & 3.074 & 3.044 & 0.989 & 0.991 & 0.992 & 0.992 & 0.990 \\
\hline Z & 2.860 & 2.825 & 2.810 & 2.784 & 2.757 & 0.989 & 0.988 & 0.995 & 0.991 & 0.990 \\
\hline D & 2.767 & 2.730 & 2.720 & 2.695 & 2.660 & 0.988 & 0.987 & 0.996 & 0.991 & 0.987 \\
\hline O & 3.053 & 3.033 & 2.958 & 2.936 & 2.912 & 0.991 & 0.993 & 0.975 & 0.993 & 0.992 \\
\hline KP & 3.014 & 2.987 & 2.982 & 2.957 & 2.931 & 0.990 & 0.991 & 0.998 & 0.992 & 0.991 \\
\hline P4 & 2.950 & 2.912 & 2.913 & 2.885 & 2.847 & 0.986 & 0.987 & 1.000 & 0.990 & 0.987 \\
\hline WM & 3.011 & 2.981 & 3.009 & 2.981 & 2.946 & 0.986 & 0.990 & 1.009 & 0.991 & 0.988 \\
\hline
\end{tabular}

Source: BRZEZICKA, WIŚNIEWSKI 2015.

The obtained results were used to realize the study aim, which was adopting research instruments of the discussed phenomenon for the needs of determining groups of similar voivodeships and the rate and level of economic development of the regions. The realization of each of the three mentioned partial aims was assumed in the following subchapters of the work.

\subsection{Classification of voivodeships into groups by similarity}

Based on the constructed and calculated $W_{0}$ and $W_{1}$ subject translocality coefficients, cluster analysis was conducted in order to classify voivodeships into groups by similarity. The first step was carrying out the standardization of variables (values of coefficients); next, a study was conducted on the standardized data in three variants, i.e.: 1) based on $\left.W_{0}, 2\right)$ based on $\left.W_{1}, 3\right)$ based on $W_{0}$ and $W_{1}$ simultaneously.

Cluster analysis on the basis of $W_{0}$ was carried out using case-based grouping (voivodeships) by the single connection agglomeration method with a measure of Euclidean distance between clusters. The obtained dendrogram and agglomeration run chart have been presented in Figure 3 and Figure 4.

The obtained results did not make it possible to distinguish homogenous clusters, therefore cluster analysis using the k-means algorithm was carried out, establishing 5 clusters and 20 iterations. Initial cluster centers were established using the distance sorting function and accepting observations at a steady interval. The obtained results made it possible to distinguish the following clusters:

- cluster 1: L3, P4,

- cluster 2, P3, Z,

- cluster 3: M2, L2, S2, W, O, KP, WM,

- cluster 4: P2,

- cluster 5: L, M, S, D. 
Dendrogram

Single connection

Euclidean distance

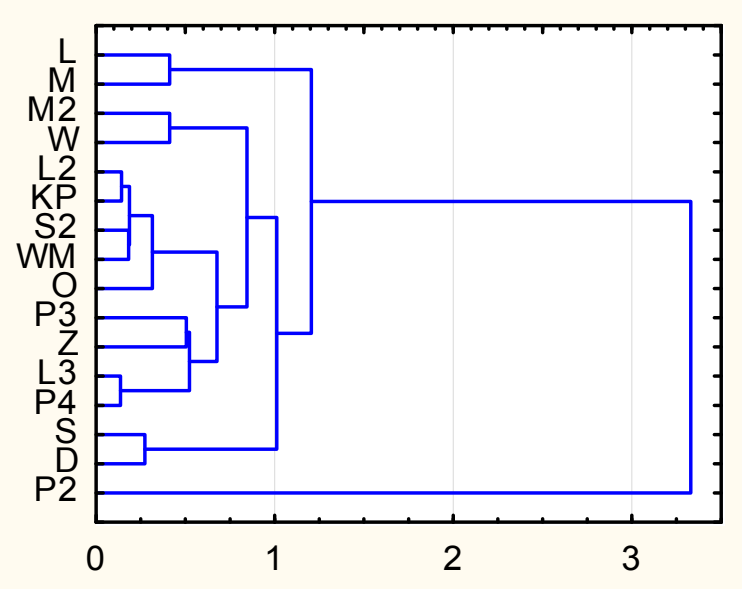

distance between connections

Fig. 3. Dendrogram for $W_{0}$. Source: own elaboration.

\section{Dendrogram}

Single connection

Measure of Euclidean distance

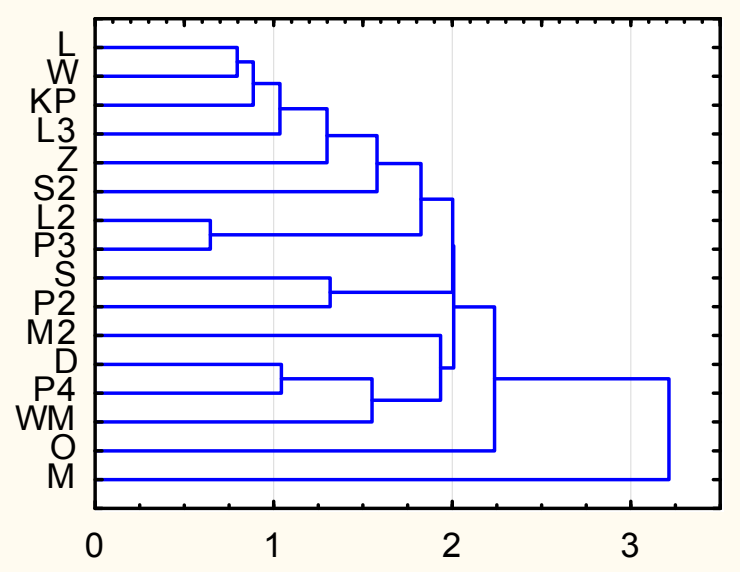

Distance of connection

Fig. 6. Dendrogram for $W_{1}$. Source: own elaboration.

\section{Graph of distance in relation to phases of connection}

Euclidean distance

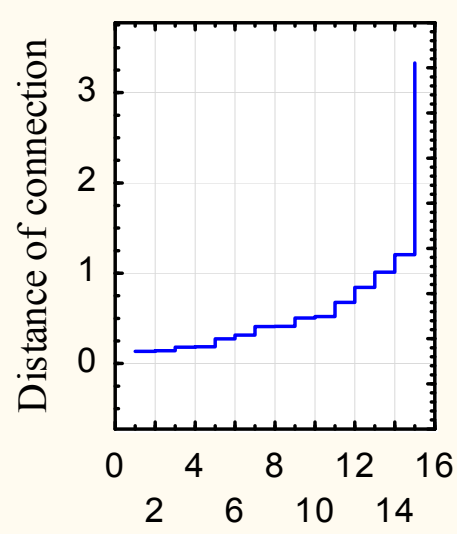

Step

Distance

Fig. 4. Graph of distance of connection for $W_{0}$. Source: own elaboration.

\section{Graph of connection distance in relation to stages of connection}

Euclidean distance

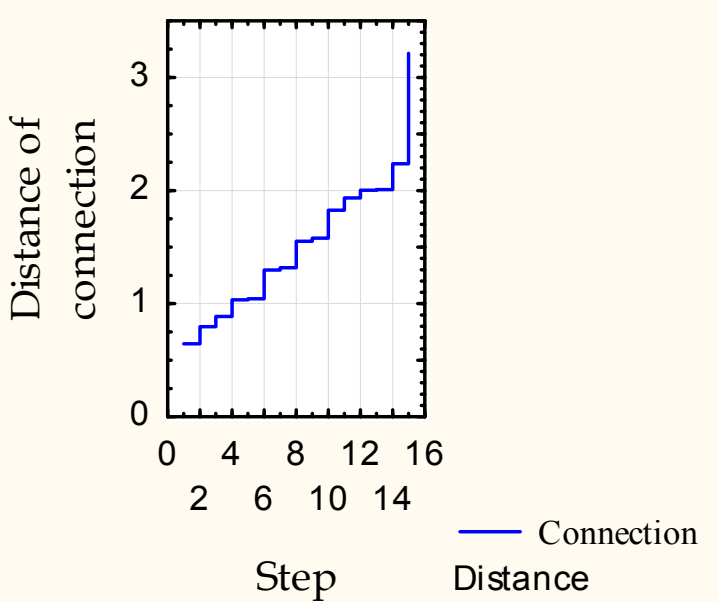

Fig. 6. Graph of connection distance for $W_{1}$. Source: own elaboration.

Cluster analysis on the basis of $W_{1}$ was performed using case-based grouping (voivodeships) by the single connection agglomeration method with a measure of Euclidean distance between clusters. The obtained dendrogram and agglomeration run chart have been presented in Figure 5 and Figure 6 .

Also in this case, the obtained results did not make it possible to distinguish homogenous clusters, therefore cluster analysis using the k-means algorithm was carried out, case-based grouping (voivodeships) was applied, establishing 5 clusters and 20 iterations. Initial cluster centers were established using the distance sorting function and accepting observations at a constant interval. The obtained results made it possible to distinguish 5 clusters: 
- cluster 1: M,

- cluster 2: L, S2, L3, W, Z, O, KP,

- cluster 3: L2, P3, D, P4,

- cluster 4: M2, WM,

- cluster 5: S, P2.

Cluster analysis based on $W 1$ and $W 2$ was carried simultaneously out using the same methods, i.e.: case-based grouping (voivodeships) by the single connection agglomeration method with a measure of Euclidean distance between clusters. The obtained dendrogram and agglomeration run chart have been presented in Figure 7 and Figure 8.

\section{Dendrogram}

Single connection

Euclidean distance

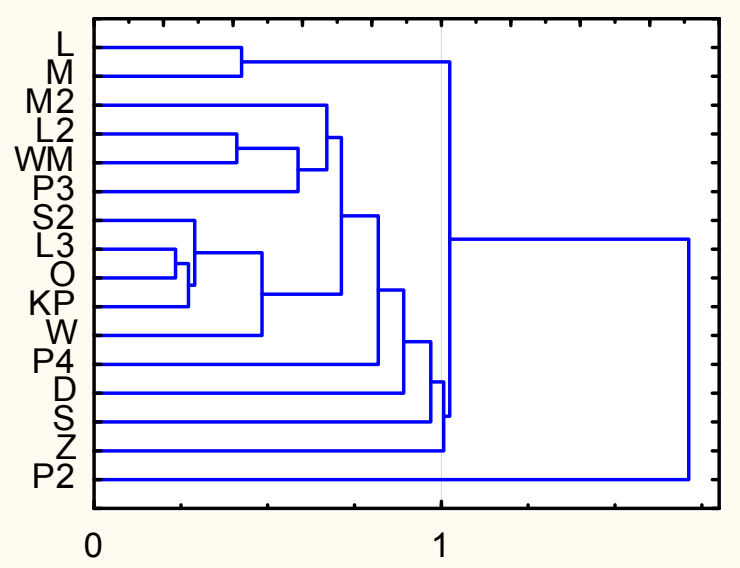

Connection distance

Fig. 7. Dendrogram for $W_{0}$ and $W_{1}$. Source: own elaboration.
Graph of connection distance in relation to stages of connection

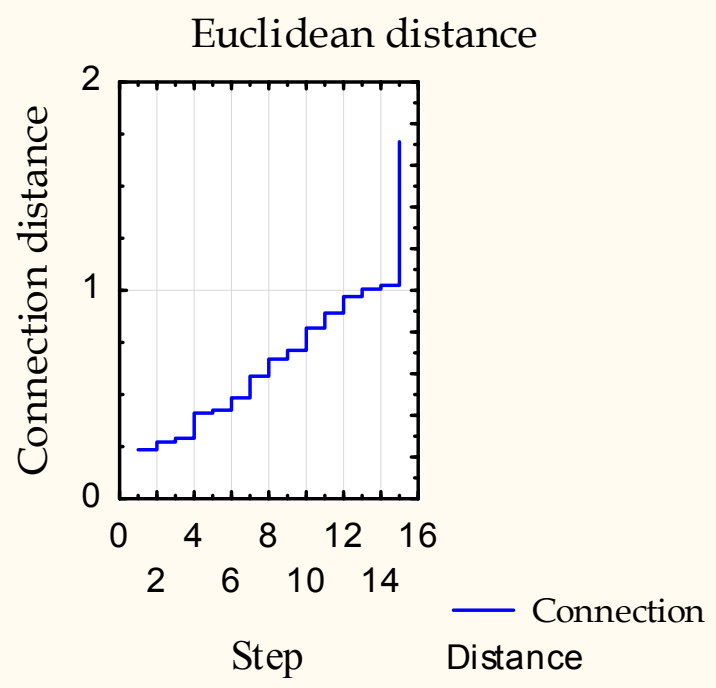

Fig. 8. Graph of connection distances for $W_{0}$ and $W_{1}$. Source: own elaboration.

The results obtained, once again, did not make it possible to distinguish homogenous clusters, therefore cluster analysis using the k-means algorithm was carried out as before. Initial cluster centers were established using the distance sorting function and accepting observations at a constant interval. The obtained results made it possibleto distinguish 5 clusters:

- cluster 1: L, M, Z,

- cluster 2: S2, L3, O, KP,

- cluster 3, M2, P2, W,

- cluster 4, S

- cluster 5: L2, P3, D, P4, WM.

The analysis carried out makes it possible to state that drawing conclusions regarding market states is made difficult due to the significant dynamics of changes over time and significant discrepancies between results depending on the applied method. Research conducted using cluster analysis did not make it possible to distinguish homogeneous groups of similarities and confirm their occurrence using different research methodology (agglomeration method, k-means algorithm) and another methodology of identifying coefficients $\left(W_{0}\right.$ and $\left.W_{1}\right)$.

At the same time, the conducted studies justify intensifying analyses connected with the issue of translocality and the subject plane of the real estate market. Studies carried out based on the $W_{0}$ coefficient (simple linear relation between the number of dwellings and number of people) lead to different results than studying the relation between these categories expressed by a dynamic means $\left(W_{1}\right.$ coefficient presents the relations between the dynamics of the number of dwellings and dynamics of the population). This means that in the real estate market system, many non-specific mechanisms, 
the course and results of which are not completely known, take place, but which will not remain without influence on later courses of many market processes.

\subsection{Analysis of the level of regional development of Polish voivodeships}

An analysis of the level of regional development can be carried out on the basis of the $W_{0}$ coefficient. The $W_{0}$ coefficient expressing the linear relation between the number of people and the number of dwellings makes it possible to determine how many people (on average) there are per one dwelling. In this way, it becomes a measure of the efficiency of the housing policy, accounting for the building sector as well as demographic fluctuations, thus the conviction that it can be used to measure the level of regional development. The efficiency of the housing policy is significant due to the long-term nature of the observed processes. On one hand, the investment cycle connected with making new flats fit for service is time-consuming and requires a lot of funds. On the other hand, generational transformations and demographic structure do not change in the short-term perspective but in the medium- and long-term one ${ }^{1}$.

The assumptions made in this study are as follows: The number of people per one dwelling is a measure of the availability of housing in a given region or voivodeship. The fewer people there are per one dwelling, the higher the efficiency of the housing policy (accounting for spontaneous demographic changes, i.e. the number of new births in each year or the number of deaths, which influence the policy but are not steered by it - unidirectional relationship.

Analyzing the level of development in the individual voivodeships of the country based on the component of real estate market subject translocality expressed by $W_{0}$ was carried out by referring $W_{0}$ values of the individual voivodeships to the $W_{0}$ value calculated for the entire country. On this basis, reduced coefficients $\left(W_{0}{ }^{\prime}\right)$ calculated in accordance with formula (3) were obtained. The calculated reduced coefficients have been compiled in Table 3 and graphically presented in Figure 9. It is worth adding that, in accordance with the proposed methodology, a value of " 0 " for the reduced coefficient signifies a value identical to that of the entire country. This means that " 0 " becomes a reference value, expressing the average national level of $W_{0}$ (red line in Figure 9).

$$
W_{0}{ }^{x}=W_{0} P-W_{0} W
$$

where:

$W_{0}^{\prime} \quad$ - reduced $W_{0}$ coefficient for individual voivodeships in year $t$,

$W_{0} P-W_{0}$ coefficient for Poland in year $t$,

$W_{0} W-W_{0}$ coefficient for a given voivodeships in year $t$.

The studies carried out made it possible to determine the development level of voivodeships based on the availability of dwellings. The study had a dynamic character - the level of development was not analyzed for the individual years but for a 5-year time span. Groups of voivodeships with a similar, comparable level of housing availability have been indicated in Figure 9:

- The group of voivodeships with the highest level of housing availability (Group 1, Figure 9) consists of: M (Mazowieckie), L (Łódzkie), D (Dolnośląskie), and S (Śląskie). In these voivodeships, in all the analyzed years, the level of housing availability exceeded the national level (highest values obtained for the Mazowieckie voivodeship, even 0.3 people/dwelling fewer than for the area of the entire country in 2012).

- The group of voivodeships with a level of housing availability oscillating around that of the national level contains the $Z$ (Zachodniopomorskie) and P3 (Podlaskie) voivodeships - Group 2 in Figure 9. In these voivodeships, the measurement in the first year under analysis was lower than the national average, but increased in the following years, exceeding the national level.

- Group 3 of the level of housing availability (number of people per one dwelling in the range of 0 to -.04 people/dwelling more than the national average, and a level of under 0 for the entire period of analysis) included the: P4 (Pomorskie), L3 (Lubuskie), KP (Kujawsko-Pomorkie) WM (Warmińsko-Mazurskie), O (Opolskie), S2 (Świętokrzyskie), M2 (Małopolskie), W (Wielkopolskie) and L2 (Lubelskie) voivodeships.

\footnotetext{
${ }^{1}$ In this perspective, the $W_{1}$ coefficient analyzes a fragment of the assumed subject area. Researching the efficiency of the housing policy based only on quantitative indicators, without accounting for the qualitative dimension, enables the assessment of selected aspects of housing policy. At the same time, the $\mathrm{W}_{1}$ coefficient can be viewed not only as a measure of regional development but also as a component (expression) of this development.
} 
- The last group was made up of only one voivodeship - P2 (podkarpackie). In this voivodeship, the number of people per one dwelling is the highest and exceeds 0.5 people/dwelling.

The most important conclusions that can be drawn from the study confirm the generally observed tendencies that the voivodeships with best "condition" of the housing policy are Mazowiecki and Łódzkie, with Podkarpackie voivodeship being characterized by the worst state. A tendency can also be observed that voivodeships considered to be the poorest also exhibit the lowest availability of dwellings.

Table 3

Value of reduced $W_{0}^{\prime}$ coefficients

\begin{tabular}{|c|c|c|c|c|c|c|c|c|c|c|c|}
\hline \multirow{2}{*}{ Year } & \multicolumn{9}{|c|}{$W_{0}^{\prime}$} & \multirow{2}{*}{ Year } & \multicolumn{3}{|c|}{$W_{0}^{\prime}$} \\
\cline { 2 - 8 } & 2008 & 2009 & 2010 & 2011 & 2012 & & 2008 & 2009 & 2010 & 2011 & 2012 \\
\hline $\mathbf{P}^{*}$ & $\mathbf{2 . 9 0 0}$ & $\mathbf{2 . 8 6 9}$ & $\mathbf{2 . 8 6 0}$ & $\mathbf{2 . 8 3 6}$ & $\mathbf{2 . 8 0 8}$ & $\mathbf{P}^{*}$ & $\mathbf{2 . 9 0 0}$ & $\mathbf{2 . 8 6 9}$ & $\mathbf{2 . 8 6 0}$ & $\mathbf{2 . 8 3 6}$ & $\mathbf{2 . 8 0 8}$ \\
\hline P $^{* *}$ & 0.000 & 0.000 & 0.000 & 0.000 & 0.000 & $\mathrm{P}^{* *}$ & 0.000 & 0.000 & 0.000 & 0.000 & 0.000 \\
\hline L & 0.160 & 0.182 & 0.203 & 0.225 & 0.252 & L3 & -0.129 & -0.101 & -0.111 & -0.085 & -0.062 \\
\hline M & 0.158 & 0.198 & 0.255 & 0.274 & 0.298 & W & -0.346 & -0.317 & -0.292 & -0.266 & -0.236 \\
\hline M2 & -0.296 & -0.253 & -0.292 & -0.268 & -0.234 & Z & -0.052 & -0.017 & -0.002 & 0.024 & 0.051 \\
\hline S & 0.075 & 0.094 & 0.076 & 0.094 & 0.114 & D & 0.041 & 0.078 & 0.088 & 0.113 & 0.148 \\
\hline L2 & -0.207 & -0.177 & -0.165 & -0.132 & -0.099 & O & -0.245 & -0.225 & -0.150 & -0.128 & -0.104 \\
\hline P2 & -0.607 & -0.583 & -0.627 & -0.601 & -0.572 & KP & -0.206 & -0.179 & -0.174 & -0.149 & -0.123 \\
\hline P3 & -0.097 & -0.066 & -0.055 & -0.022 & 0.011 & P4 & -0.142 & -0.104 & -0.105 & -0.077 & -0.039 \\
\hline S2 & -0.221 & -0.201 & -0.207 & -0.178 & -0.150 & WM & -0.203 & -0.173 & -0.201 & -0.173 & -0.138 \\
\hline
\end{tabular}

* $W_{0}$ coefficient for Poland, ${ }^{*} W_{0}^{\prime}$ coefficient for Poland. Source: own elaboration.

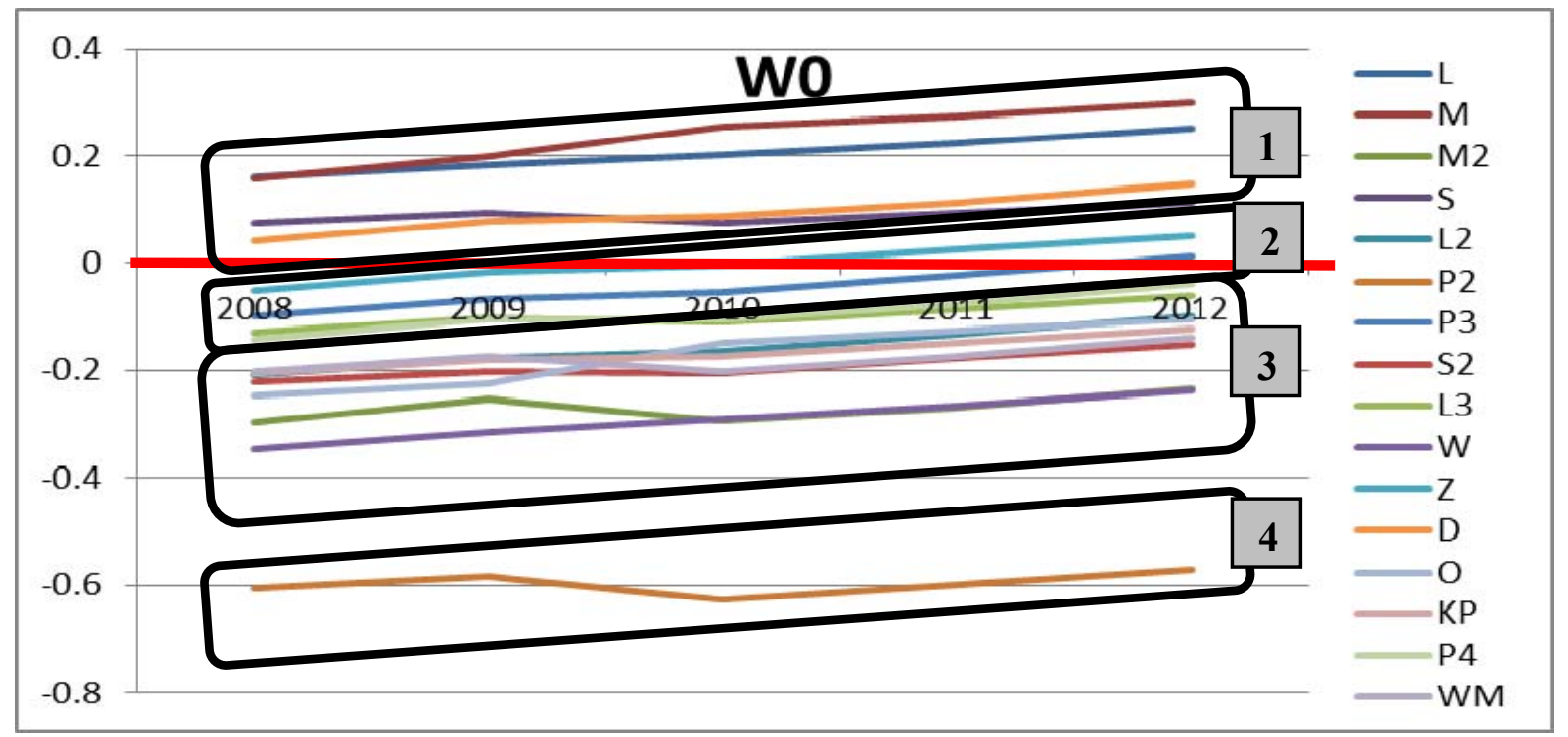

Fig. 9. Value of reduced $W_{0}^{\prime}$ coefficients. Source: own elaboration.

\subsection{Analysis of the rate of regional development of Polish voivodeships}

The analysis of the rate of regional development of Polish voivodeships was carried out on the base of the $W_{1}$ coefficient; the very methodology of calculating this coefficient calls for a dynamic approach. The following assumption was made in the studies: the rate of development is expressed by the rate at which the $W_{1}$ coefficient increases:

- if $W_{1}>1$, this means that the increase in the number of people in the given unit of time was higher than in the increase in the number of dwellings,

- if $W_{1}<1$, this means that the increase in the number of dwellings in the given unit of time was higher than the increase in the number of people. 
The above made observations make it possible to assume that the lower $W_{1}$ is from year to year, the faster the rate of development (increase of housing availability), this means that the lower the increase in the $W_{1}$ coefficient, the (relatively) faster the rate of development. The relativity of the rate of increase is dependent on the double-sided nature of the observed values (the increase in the number of dwellings as well as decrease in the number of people); the authors of the article consider the described relativity to be a restriction of the study that could not be left out.

Based on the assumptions made, the rate of increase of the $W_{1}$ coefficient was assessed in the individual years, calculating reduced $W_{1}^{\prime}$ coefficients according to formula (4). The calculations of reduced coefficients have been compiled in Table 4 and Figure 10.

$$
W_{1}^{T}=W_{L i g}-W_{1 ;-12}
$$

where:

$W_{1}^{\pi} \quad$ - reduced $W_{1}$ coefficeint,

$W_{1}$ (t) $-W_{1}$ coefficient in $t$ unit of time,

$W_{1,-18}-W_{1}$ coefficient in $t-1$ unit of time.

Table 4

Value of reduced $W_{1}{ }^{\prime}$ coefficients

\begin{tabular}{|c|c|c|c|c|c|c|c|c|c|c|c|}
\hline \multirow{2}{*}{ year } & \multicolumn{5}{|c|}{$W_{1}^{\prime}$} & \multirow{2}{*}{ year } & \multicolumn{5}{|c|}{$W_{1}^{\prime}$} \\
\hline & 2008 & 2009 & 2010 & 2011 & 2012 & & 2008 & 2009 & 2010 & 2011 & 2012 \\
\hline L & -0.001 & 0.001 & 0.001 & 0.000 & -0.002 & L3 & -0.003 & 0.002 & 0.013 & -0.012 & 0.001 \\
\hline $\mathrm{M}$ & -0.005 & 0.000 & -0.007 & 0.014 & -0.002 & W & -0.003 & 0.002 & 0.001 & 0.000 & -0.001 \\
\hline M2 & -0.004 & -0.001 & 0.027 & -0.021 & -0.003 & Z & 0.000 & -0.002 & 0.007 & -0.004 & 0.000 \\
\hline$S$ & 0.000 & 0.002 & 0.013 & -0.013 & -0.001 & D & -0.003 & -0.001 & 0.009 & -0.005 & -0.004 \\
\hline L2 & -0.001 & 0.002 & 0.006 & -0.007 & 0.000 & $\mathrm{O}$ & -0.001 & 0.002 & -0.018 & 0.017 & -0.001 \\
\hline P2 & 0.000 & 0.000 & 0.020 & -0.020 & -0.001 & KP & -0.004 & 0.001 & 0.007 & -0.007 & 0.000 \\
\hline P3 & 0.000 & 0.001 & 0.007 & -0.008 & 0.000 & $\mathrm{P} 4$ & -0.003 & 0.001 & 0.013 & -0.010 & -0.003 \\
\hline S2 & -0.001 & 0.002 & 0.008 & -0.011 & 0.000 & WM & -0.002 & 0.004 & 0.019 & -0.018 & -0.003 \\
\hline
\end{tabular}

Source: own elaboration.

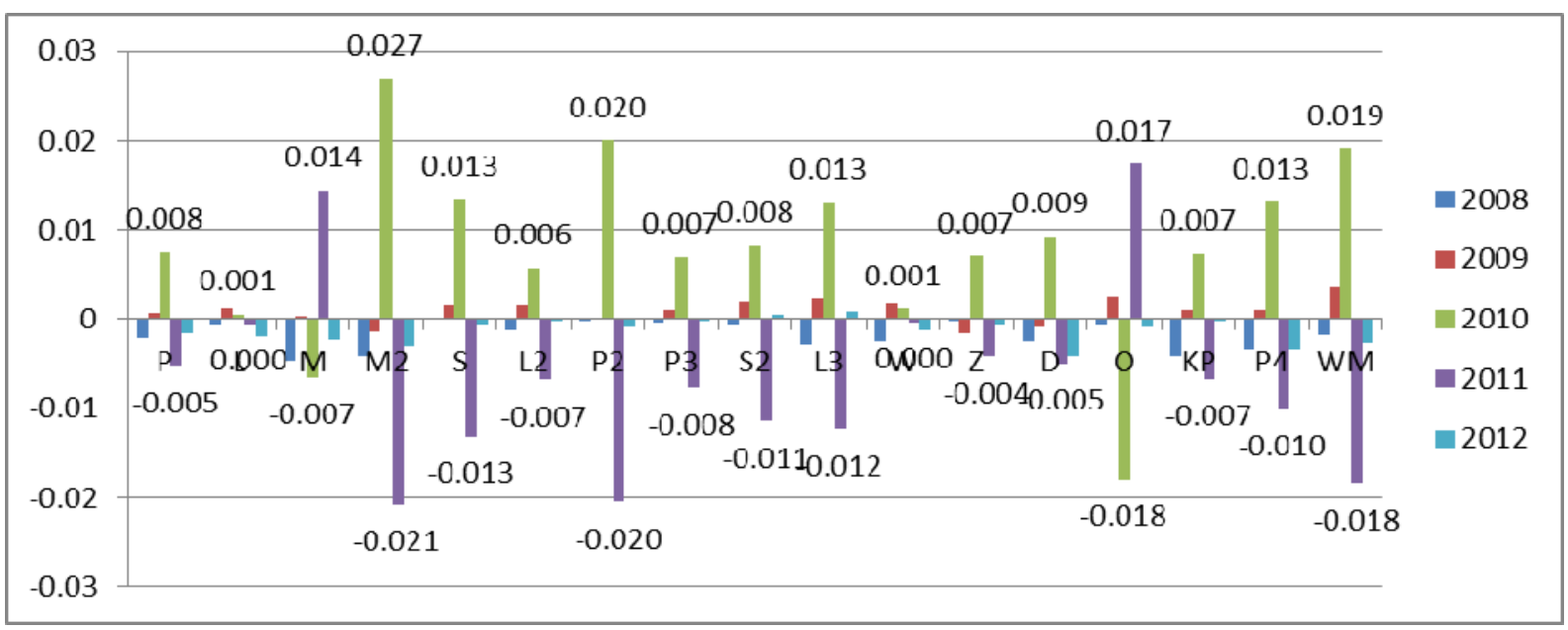

Fig. 10. Value of reduced $W_{1}^{\prime}$ coefficients. Source: own elaboration.

The research carried out made it possible to assess the increases in the coefficient over time, revealing an interesting phenomenon - a collapse of market structures in the years 2010 and 2011. Increases in the years prior to the phenomenon (i.e. 2008 and 2009) are at a moderate level, oscillating near zero (values do not exceed \pm 0.005 ). Similarly, following the observed phenomenon (in the year 2012) a return of the levels of increase oscillating near zero is observed. The years 2010 and 2011 reveal the indicated turbulence and show significant rises and drops in the $W_{1}$ coefficient, to the level of 0.025, which indicates anywhere from a few to a few dozen times higher increase/decrease in the levels of the analyzed coefficients. As indicated by Table 2 in Chapter 4.3 - a significant collapse in the 
level of the $W_{1}$ coefficient took place in the year 2010, causing a symmetric reflection of values neighboring the year 2010. As indicated by BRZEZICKA and WISNIEWSKI (2015), a "mirror image of the trend" occurred following the year 2010. "In the year 2011, the value of the $W_{1}$ indicator returns to the norm prior to the shock." Such trajectories of the analyzed categories reflect certain market tendencies for untypical phenomena to be created on this market (the real estate market is a nonspecific market). Their observation and analysis can be an interesting example confirming the thesis of the proposed subject translocality on the REM, while explaining the presented state of the market can be of fundamental importance to confirming the thesis regarding the translocality of the real estate market. It's worth reminding that the $W_{1}$ coefficient pertains to the dynamics of the number of people in relation to the dynamics of the number of dwellings. The analysis of the partial values of $W_{1}$ makes it possible to notice that the dynamics that are components of the $\mathrm{W}_{1}$ coefficient are significantly different, which means that the directions of changes in the subject and object plane of the real estate market are not concurrent, and follow two trajectories with certain common elements. A common tendency can be observed up to the year 2008 (the beginning of the crisis). The development of the economic crisis, including the crisis revealed in the real estate market, influence disturbances in the, up to then stable, tendency. The observation of the levels of reduced $W_{1}^{\prime}$ coefficients serves as confirmation of the occurrence of the phenomenon of real estate market subject translocality.

\section{Summary and conclusions}

Detailed conclusions drawn from the carried out research, pertaining to the development level and rate of voivodeships and their classification into similar groups, are contained in the text; this is why it is worth formulating a few generally observed tendencies when summarizing the work. The above analyses make it possible to draw attention to the substantial importance of the issue of subject translocality in analyzing the real estate market as well as the significant role of active participants in the market game. The developed coefficients of translocality, as well as their adaptation to analyzing various market phenomena (including the level and rate of the development of regions), make it possible to study the behaviors of mobile participants in the market sphere in greater detail. It is worth highlighting that it is the participants who, by and large, influence the mechanisms of how the real estate market functions, and it is the participants who display the property of changing the real estate market system, though their role in market analysis appears to be undervalued.

\section{References}

APPADURAi A., 1996, Modernity at Large: Cultural Dimensions of Globalization, Minneapolis: University of Minnesota Press.

BRZEZICKA J., WISNIEWSKI R., 2014a, Price bubble in the real estate market - behavioral aspect, Real Estate Management and Valuation, No. 22(1), pp. 80-93.

BRZEZICKA J., WISNIEWSKI R., 2014b, Identifying selected behavioral determinants of risk and uncertainty on the real estate market, Real Estate Management and Valuation, No. 22(2), pp. 30-40.

BRZEZICKA J., WISNIEWSKI R., 2014c, Wybrane postawy uczestników rynku wobec braków informacyjnych na rynku nieruchomości (Selected attitudes of market participants with respect to information gaps in real estate market), Ekonomia XXI wieku, No. 2 (2), pp. 106-121

BRZEZICKA J., WISNIEWSKI R., 2014d, Homo oeconomicus and Behavioral Economics, Contemporary Economics, No. 8(4), pp. 353-364.

BRZEZICKA J., WISNIEWSKI R., 2015, Tanslocality on the real estate market, Land Use Policy, praca w recenzji.

ELAFrOS A., 2013, Greek hip hop: Local and translocal authentication in the restricted field of production, Poetics, No. 41(1), pp. 75-95.

FREITAG U., VON OPPEN A., 2010, Translocality: the study of globalising processes from a southern perspective, Vol. 4, Brill.

Galaty F. W., Allaway W.J., Kyle R.C., 2003, Modern real estate practice in North Carolina, Dearborn Real Estate.

GELTNER D., 2007, Commercial real estate: Analysis \& investments, Cengage learning.

GŁÓWKA G. (red.), 2008, Nieruchomość, kredyt, hipoteka, Wydawnictwo Poltext, Warszawa.

GoŁĘBSKA E. (red.), 2007, Rynek nieruchomości i jego podmioty, Wydawnictwo Wyższej Szkoły finansów i Zarządzania w Białymstoku, Białystok. 
GREINER C., SAKDAPOLRAK P., 2013, Rural-urban migration, agrarian change, and the environment in Kenya: a critical review of the literature, Population and Environment, No. 34, pp. 524-553.

HAILA A., 2000, Real estate in global cities: Singapore and Hong Kong as property states, Urban Studies, nr 37(12), pp. 2241-2256.

HALL S., DATTA A., 2010, The translocal street: Shop signs and local multi-culture along the Walworth Road, south London, City, Culture and Society, No. 1(2), pp. 69-77.

HANNERZ U., 1998, Transnational research. Handbook of Methods in Cultural Anthropology, ed. H. Russell Bernard (Walnut Creek, London, New Delhi: Altamira, 1998), pp. 235-256.

HOPFER A., CELlmer R., 1997, Rynek nieruchomości, Olsztyn: Wydawnictwo ART.

KAŁKOWSKI L. (red.)., 2001, Rynek nieruchomości w Polsce, Wydawnictwo Twigger, Warszawa.

KŁOBUKOWSKA J. 2014, Zachowania inwestycyjne na rynku nieruchomości w świetle założeń ekonomii behawioralnej-problemy metodologiczne, Pieniądze i Więź, No. 17(1 (62)), pp. 140-148.

KUCHARSKA-STASIAK E., ZAŁĘCZNA M., ŻELAZOWSKI K., 2012, Wptyw procesu integracji Polski z Unia Europejska na rozwój rynków nieruchomości, Wydawnictwo Uniwersytetu Łódzkiego, Łódź.

KUCHARSKA-STASIAK E., 2006, Nieruchomość w gospodarce rynkowej, PWN, Warszawa.

LUCIUS D.I., 2001, Real options in real estate development, Journal of Property Investment \& Finance 19(1): 73-78.

LuSHT K.M., 1988, The real estate pricing puzzle, Real Estate Economics, No. 16(2), pp. 95-104.

MA E.K.W., 2002, Translocal spatiality, International Journal of Cultural Studies, No. 5(2), pp. 131-152.

MASIUKIEWICZ P., DEC P., 2013, Czynniki kreacji bańki cenowej na rynku nieruchomości, Annales Universitatis Mariae Curie-Skłodowska, Sectio H Oeconomia, No. 3, pp. 401-408.

SIEMIŃSKA E. (red.), 2011, Inwestowanie na rynku nieruchomości, Wydawnictwo Poltext, Warszawa.

SMITH M.P., 2001, Transnational Urbanism: Locating Globalization, Malden, MA and Oxford: Blackwell.

SMITH M.P., 2005, Power in Place/Places of Power: contextualizing transnational research, City \& Society, nr 17(1), pp. 5-34.

Ustawa z dnia 23 kwietnia 1964 r. - Kodeks cywilny (Dz.U. 1964 nr 16 poz. 93 z późn. zm.).

WISNIEWSKI R., 2007a, Wielowymiarowe prognozowanie wartości nieruchomości (Multidimensional forecasting of real estate value), Wydawnictwo Uniwersytetu Warmińsko-Mazurskiego.

WISNIEWSKI R., 2007b, Efficient real estate market, Studia i Materiały Towarzystwa Naukowego Nieruchomości, No. 1-2, pp. 103-113. 